\title{
Translation of a Selection of Caitríona O'Reilly's Poems into Spanish
}

\author{
Luz Mar González-Arias (Introduction and Translations)
}

Copyright (C) 2018 by Caitríona O'Reilly and Luz Mar González-Arias. This text may be archived and redistributed both in electronic form and in hard copy, provided that the author and journal are properly cited and no fee is charged for access.

\section{Beyond the Contemplative: Caitríona O'Reilly's Spain}

Irish poet Caitríona O'Reilly (Dublin, 1973) has published three books of poetry to date. Her debut collection, The Nowhere Birds (Bloodaxe, 2001), described by Selina Guinness as a work of "poised alertness to tremors of change" (259), was shortlisted for the Forward Prize for Best First Collection in 2001, and won the Rooney Prize for Irish Literature in 2002. Her second collection, The Sea Cabinet (Bloodaxe, 2006), shortlisted for the prestigious Irish Times Poetry Now Award, was Poetry Book Society Recommendation in 2007. With Geis, her latest collection (Bloodaxe, 2015), O'Reilly won the Irish Times Poetry Now Award in 2016. She has been editor of Poetry Ireland Review and has also been widely published as a literary critic. The selection of poems translated into Spanish for Estudios Irlandeses are all taken from The Sea Cabinet (2006): "Diffraction" (17-18), the sequence "In the Deaf Man's House" (28-29), "VI In Aragón" (36), "III The Lure" (52), and "Pollen" (59). In all of them O'Reilly presents us with her very personal, sometimes even intimate, perception of Spain, where she was on a travel grant - the Harper Wood Studentship from St John's College, Cambridge - in 2003. For a few months, the poet visited Madrid and Barcelona, Toledo, Aragón and Segovia, and these poems are a response to her encounter with the artistic as well as physical landscapes of Spain.

In "Diffraction" (O'Reilly 17-18), the poetic persona experiences symptoms that might suggest a heatstroke but that, on a careful reading, might also be triggered by the strange magnificence of the landscapes before her eyes. The reference to "ants" and "flies" in this text reminds us of the strong presence of insects in The Nowhere Birds, where, as Selina Guinness has pointed out, natural imagery either "terrifies" or "expresses libidinal desires intimately understood" (259). In "Diffraction", this tension between attraction and repulsion ultimately contributes to the overwhelming emotion of the poetic eye. We could contend that the so-called Stendhal syndrome, which causes dizziness, even hallucinations, when an individual is exposed to the viewing of particular works of art, is extended here to the experience of the world of nature.

The poems in the sequence "In the Deaf Man's House" (28-29) are inspired by Francisco de Goya's work, in particular by the grotesqueness of the human figures and scenes represented in his black paintings. The reference to "prognathous Jane, old rot-nose / cavorting with devils in her sleep, / sucking the penis of a billy goat, / or vomiting prophetic eggs" (28) perfectly captures the eerie and disquieting nature of this imagery. Goya and his characters inhabit the five poems of the sequence and merge with the voice of the poetic persona to such an extent that at times they become indistinguishable. Hence, the first person pronoun singular in the title of the second poem in the sequence, "Yo lo vi" (28), a literal 
transcription of Goya's Yo lo vi (I Saw It), from his series The Disasters of War, becomes the powerful presence of the poetic I/eye that witnesses, and experiences, not only the work of art but also the reality surrounding it.

Far from being a mere object of contemplation, the landscape is humanised in "In Aragón" (36): the vertical lines of the trees in Caspe contrast with the "horizontal faces" of its hills, their "fractured hearts" and "their fractured bones". The fusing of the human and the non-human is thus eloquently achieved by this exploration of the corporeal dimension of nature. O'Reilly makes use of the specific terminology of falconry in "The Lure" (52). Once more, the poem focuses on elements of the natural world, in this case the Spanish águila as she describes her "brutal circle" over the Segovian plain. The opening lines of the poem "[s]nared in a mode of seeing, / the raptor's eyes unseel again" - speak of the now banned practice of seeling, or stitching the eyelids of the bird together to reduce sensory intensity. However, these lines can also be read as a reflection on the subject's visual relationship with nature. The visual has always been a privileged way of apprehending the world, producing, as it were, the illusion of an objective reality. But "The Lure" inscribes the landscapes of the interior as much as those of the Segovian plain, especially in its poignant closing line, where the earth becomes "the World, the Flesh, the Devil". Finally, in "Pollen" (59), O'Reilly uses the spice of azafrán to reflect on the existential effect of its colour on the poetic voice "[e]ven now I can barely contemplate / its brightness in the eye of the bee". As in "Diffraction", we perceive here the overwhelming beauty of the natural surroundings and their uncanny - in the Freudian sense of the word - dimension.

Caitríona O'Reilly is part of a long list of Irish writers, artists and poets that have found inspiration in Spain. Barcelona, Madrid, Seville, and the Mediterranean coasts would be among the places most frequently revisited by Irish authors in their work. Instead, O'Reilly focuses on the natural and artistic resources of Aragón and Segovia, providing her audiences - Spanish and international alike - with a lesser-known part of the country. To make use of one of the most powerful images in these poems, when reading O'Reilly we can see the poet experiencing - rather than contemplating - the Spanish landscapes she has encountered, and writing words that will bring them to light, to that "fiat lux" state of "The Lure": Let There Be Light on what lies outside and inside the I/eye. Let there be light. Let there be poets.

\section{Works cited}

Guinness, Selina, ed. The New Irish Poets. Tarset: Bloodaxe Books, 2004.

O'Reilly, Caitríona. The Sea Cabinet. Tarset: Bloodaxe Books, 2006. 


\section{DIFFRACTION}

Eil qui gardes en toi

Tant de sommeil sous un voile de flamme...

PAUL VALÉRY

The electrical cicadas, the little brown lizards, here on the hill

light's own properties colour the landscape in. Those rocks on which

the theatre perches are from the Greek: sand-gold sea bullion,

and in the high cemetery the cenotaphs' duty is to face an impossible blue.

I stumble among them in the heat-struck noon, seeking a tomb

by the lavender beds.

The sun-strained sea.

The thousand gazing sails

of the dead.

And the light -

it fills my eye-vessels

to overflowing, shifting

the rods and cones

of their ravenous geometry.

Not the Catalan woods, their calm green, their shy beasts out of Rousseau,

can rub from my sight

this dazzle.

Days later I notice it -

a half-moon gone,

half a sentence

smudged from the page.

It was the dark

ajar in my head,

a portion so aswarm

with ants or flies

it was invisible.

\section{DIFRACCIÓN}

Cil qui gardes en toi

Tant de sommeil sous un voile de flamme...

PAUL VALÉRY

\author{
Cigarras eléctricas, \\ pequeñas lagartijas amarronadas, \\ aquí en el cerro \\ las propias propiedades de la luz \\ dan color al paisaje. \\ Aquellas rocas donde \\ se asienta el teatro \\ son de los griegos: \\ un mar de lingotes dorados, \\ y más arriba, en el cementerio, \\ la misión de los cenotafios \\ es enfrentar un azul imposible.
}

Avanzo torpemente entre ellos en el intenso calor de mediodía, buscando una tumba

entre las camas de lavanda.

El mar estriado por el sol.

La mirada de las miles de naves

de los muertos.

Y la luz -

colma los navíos de mis ojos

hasta rebosar, alterando

la geometría voraz

de las células de mi retina.

Ni los bosques catalanes, con su verde calma, con sus tímidas bestias sacadas de Rousseau,

pueden arrancar de mi vista

este resplandor.

Días más tarde me doy cuenta -

media luna ausente, media frase emborronada sobre el papel.

Era la oscuridad que se abría en mi cabeza, una parte tan repleta

de hormigas o moscas que era invisible. 
At St Pau hospital,

its medical machinery

buried in earth,

I am seen inside.

Argus, my x-ray, says:

there are limits to what

any eye can absorb.

\section{IN THE DEAF MAN’s HOUSE}

\section{Who are these coming to the sacrifice?}

The town spews forth its varlets this morning like black bile.

This view suffices me for windows.

I know the noble citizens by sight:

I have made them articulate

like a snake that clings

to the sexual outline of the earth,

their clot of moaning faces as its head, their mouths issueless as flowers

opening on walls of silence.

\section{Yo lo vi}

The matadors minced in their coats of light, the forms of women glowed like moons in my youth. Now in this bitumen-flicker I see prognathous Jane, old rot-nose cavorting with devils in her sleep, sucking the penis of a billy goat, or vomiting prophetic eggs.

I have seen it: anything may happen between these dark disordered walls.

\section{The Sleep of Reason}

My friend, you write about the cold and how the words themselves seem cancerous. On these walls faces take the place of words. I have heard nothing for many years but the animal-breath of madness in my ear. The open skies smite me with imaginary noise. I keep to my house, conjuring inquisitors from cracked plaster.

\section{Sabbath-Asmodeus}

I cannot hear my own footfalls, so like a sad sleeper kicking a foot free from twisted sheets,
En el hospital de Sant Pau,

su maquinaria médica hundida en la tierra, me miran por dentro.

Argos, mi radiografía, dice: hay límites para lo que puede absorber el ojo humano.

\section{IN THE DEAF MAN’s HOUSE}

\section{I ¿Quiénes son estos que acuden al sacrificio?}

La ciudad escupe sus lacayos esta mañana como bilis negra. Me sirve de ventana esta visión. Conozco de vista a los ciudadanos nobles: Les he hecho elocuentes como una serpiente que se adhiere a los contornos sexuales de la tierra, por cabeza la masa de sus rostros quejumbrosos, sus bocas estériles como flores que se abren sobre muros de silencio.

II Yo lo vi

Los toreros caminan con gracia abrigados en luz, las siluetas de mujeres resplandecen como lunas de mi juventud. Ahora, en el titileo del asfalto, veo a Jane, la de mandíbula saliente y nariz podrida, retozando en sueños con demonios, chupándole el pene a un macho-cabrío, o vomitando huevos proféticos.

Yo lo vi: cualquier cosa puede suceder entre el desorden y la oscuridad de estas paredes.

\section{El sueño de la razón}

Amigo mío, escribes sobre el frío y las palabras mismas resultan cancerosas. En estos muros las caras ocupan el lugar de las palabras. Durante años no he escuchado nada que no fuese la respiración animal de la locura en mis oídos. Los cielos despejados me golpean con un ruido imaginario. Me quedo en casa, y conjuro inquisidores en el yeso agrietado.

\section{Aquelarre-Asmodea}

Inaudibles para mí mis pasos, como triste durmiente que libera un pie de sábanas revueltas, 
I am condemned to dream.

Am I the one that Asmodea

smothers in her red cloak?

That town on the anvil-shaped hill

withstands the light's assaults.

Prodigiously sick and dizzy

I fall nightly over its edge.

\section{Palimpsest}

My original scheme foresaw

a fête galante of supine duchesses, majos done in daubs of flesh and silks.

Instead I watched the python Time devour them all and tore myself to bits below the unoffending sky.

Then I learned the uselessness

of light. These walls absolve me

of the years' thick impasto,

of the scrawl that became my life.

\section{In Aragón}

Caspe - a parched sigh

the earth emits at midday

when the sun's reign heightens

over hills of yellow or pale orange dirt,

studded with agave harsh enough

to have and keep its liquid core.

Seventy years since,

this earth quenched itself

to some forgotten end

(any arid cone could be another);

the Ebro holds itself still inside

its dark blue dream, and the trees

twist with the effort of rising.

In Caspe, light pours through the gap

the hills create in being at odds

with each other against the flaming sky,

and shows their horizontal faces

grooved and inscrutable in the Spanish way

and as indifferent to the force that shapes them,

giving them fractured hearts for their fractured bones. estoy condenada a soñar.

¿Soy yo la que asfixia

Asmodea con la capa roja?

La ciudad en la colina del yunque

resiste los embistes de la luz.

Prodigiosamente enferma y débil

sucumbo cada noche a sus abismos.

\section{Palimpsesto}

Mi plan inicial anticipaba una fête galante de duquesas reclinadas, majos trazados en carne y sedas.

En su lugar observé a la pitón del Tiempo

devorarlos a todos y me hice trizas

bajo un cielo sin ofensa.

Comprendí entonces la inutilidad

de la luz. Estas paredes me absuelven

de años de grueso empastado,

del garabato en que se ha convertido mi vida.

VI En Aragón ${ }^{2}$

Caspe - un suspiro reseco

que la tierra emite al mediodía

cuando el reinado del sol se alza

sobre colinas de polvo amarillo o naranja febril,

salpicadas con el rigor del agave

que retiene y conserva líquido su núcleo.

Setenta años atrás,

esta tierra se saciaba

en algún límite olvidado

(cualquier árida estructura cónica podría ser otra);

El Ebro aún se contiene

en su sueño azul intenso, y los árboles

se retuercen aspirando a la verticalidad.

En Caspe, la luz se cuela entre los huecos

de colinas discordantes

bajo un cielo encendido,

y muestra sus rostros horizontales

estriados e inescrutables a la manera española,

indiferentes a las fuerzas que les dan forma,

ofreciendo corazones rotos para sus huesos fracturados. 
THE LURE

Snared in a mode of seeing, the raptor's eyes unseel again.

Not an outline scarfing the blue wind but several worlds unscrolling:

the chemical plant's logical conduits glitter like the keys of a flute

while brown earth casts up bones of its lost alluvial people:

shards of Delft in a Dutch landscape. Abandoned churches ride the horizon

like high ships. She is caught in the rigging such details as flowers in dark grass,

calligraphic wings imped by a scribe to fiat lux, or mantling their Marian prey.

Over a bleached Segovian plain the eye seeks its eagle like the sky's pupil.

Aguila, describing a brutal circle.

Slow clouds tumble from the cooling stacks.

Anchor, tear-drop and cut diamond Now her sentimental silhouette descends

To a swung horseshow bound in leather. It is the World, the Flesh, the Devil.

\section{POLLEN}

Lying with one eye open I can see

a yellow spot staining the clean sheet

I put there yesterday,

a fleck of yolk suspended

in albumen, gold coin at the end

of a barren viscous sea

for those brave enough to stain

their lives to gild the Virgin's mantle.

Their blood mixed with foam

dries to crackling on the shores of Spain.

Azafrán - the colour of evening sun, the flavour of honey that never reaches

\section{EL CEBo $^{3}$}

Atrapados en un modo de mirar, se liberan de nuevo los ojos del águila.

Ni un contorno es devorado por el viento azul y una multiplicidad de mundos se despliega:

los lógicos conductos de la planta química brillan como llaves de una flauta

mientras la tierra rojiza escupe los huesos de extinguidos pueblos aluviales:

fragmentos de cerámica en un paisaje holandés. Iglesias abandonadas recorren el horizonte

como embarcaciones esbeltas. Queda cautiva en el mástil son detalles como flores en hierba oscura,

caligráficas alas salvadas por un escriba hasta fiat lux, o manto para una presa virgen.

Sobre la decolorada planicie segoviana el ojo busca al águila como pupila del cielo.

Águila, que describes un círculo brutal. Nubes lentas que caen sobre la hierba apilada.

Ancla, lágrima y diamante su sentimental silueta desciende ahora

hasta una herradura oscilante fraguada en cuero. Es el Mundo, la Carne, Satanás.

\section{POLEN}

Tumbada y con un ojo entreabierto puedo ver la amarilla mancha en la sábana limpia

que puse ayer,

una mota de yema suspendida

en clara, una moneda de oro en el límite de un mar yermo de viscosa

para los valientes que manchan sus vidas por cubrir de oro el manto de la Virgen.

Su sangre mezclada con espuma se seca hasta crujir en las costas de España.

Azafrán - el color del ocaso,

el sabor de la miel que nunca alcanza 
the lips, edging instead a labyrinthine Gospel, spilling its light inside the borders.

Even now I can barely contemplate its brightness in the eye of the bee,

how it dusts his muscular back and grain for grain matches his gold

in the gasp of the calyx, in the petal's ragged breath.

\author{
los labios, que se acerca a un Góspel laberíntico \\ y derrama luz dentro de sus límites. \\ Incluso ahora apenas puedo contemplar \\ aquel resplandor en los ojos de una abeja, \\ cómo sacude su espalda muscular \\ y grano a grano iguala su tono dorado \\ en el aliento del cáliz, \\ en la respiración irregular del pétalo.
}

\begin{abstract}
Notes
1 "Ojo que guardas en tu interior / tanto sueño tras una cortina de fuego..."

${ }^{2}$ N. de la T. Último poema en la secuencia "Six Landscapes" ("Seis paisajes").

${ }^{3}$ N. de la T. Tercer poema en la secuencia de cuatro "A Quartet for the Falcon" ("Un cuarteto para el halcón”).
\end{abstract}

Luz Mar González-Arias is Senior Lecturer in the English Department, University of Oviedo. Her research is primarily in the areas of body theory and Medical Humanities, as applied to the work of contemporary Irish women poets. Her publications include a chapter on Ireland in The Routledge Companion to Postcolonial Studies (2007), and an essay on the versions of Sheela-na-gigs in the poetry of Susan Connolly in Opening the Field (Cork University Press, 2007). She has contributed to the Special Issue that An Sionnach (2009) dedicated to Paula Meehan with an essay on citified embodiments in Meehan's urban poetry, and to the volume Animals in Irish Literature and Culture (Palgrave Macmillan, 2015) with her essay "“A Pedigree Bitch, Like Myself": (Non)Human Illness and Death in Dorothy Molloy's Poetry". She is the editor of National Identities and Imperfections in Contemporary Irish Literature: Unbecoming Irishness (Palgrave Macmillan, 2017). González-Arias has recently translated Éilís Ní Dhuibhne's short stories into Spanish (Un almuerzo literario y otros cuentos, ediciones KRK, 2018) and is currently working on a book-length monograph on the life and poetry of Dorothy Molloy.

luzmargonarias@gmail.com 